\title{
Reminiscences of
}

\section{This Passing Season}

\section{Ralph Stueck, Abernethy, Director}

It seems but yesterday since many of us were indoors, waiting for the first patch of bare ground. Finally it came. The snow banks began to disappear. Then one morning a Horned Lark gave his cheery note of greetingspring was on its way. Yes, and there just below the kitchen window were five little grey and white Juncos. They were joined by two Song Sparrows, then a White-crowned Sparrow with his new spring bonnet. My heart began to thump. Just wait until I get to the Qu'Appelle Valleyfor it is there that Old Mother Nature paints Spring in the heart.

We watched the migration of the birds from the south and felt indebted to the Supreme Being who has planned all these wonderful things for our enjoyment. The sloughs filled up with water; then the ducks appeared with their "quack, quack," while above the "honk, honk" of the Canada Geese could be plainly heard. It is at this season of the year, early in the morning that spring really enters wi thin your soul. With ears and eyes you are wide awake. Eagerly we listen to a distant "boom, boom", then a whirring sound of the Prairie Chicken dancing on the hill. Listen! There must be thirty or more to greet the rising sun. Then what is that distant strange "thump, thump" - then faster still "thump, thump, thump", with a whirr like distant thunder. It is the male Ruffed Grouse. There by the hour he drums on a hollow log to inform his letter half that he is not away in the woods, flirting with some other lady. Yes, friends, these are the signs of spring on the prairies.

At no place on earth do people wait more eagerly for the coming of spring, then as the curtain slowly but surely rises, once more summer is ushered in. Soon every living thing is at its best. The gardens have yielded bounteous returns. The fields of grain waved, waste high, as far as the eye could see. We cherish the thought that these prairies are yours and mine to enjoy. We think of the wheat as a

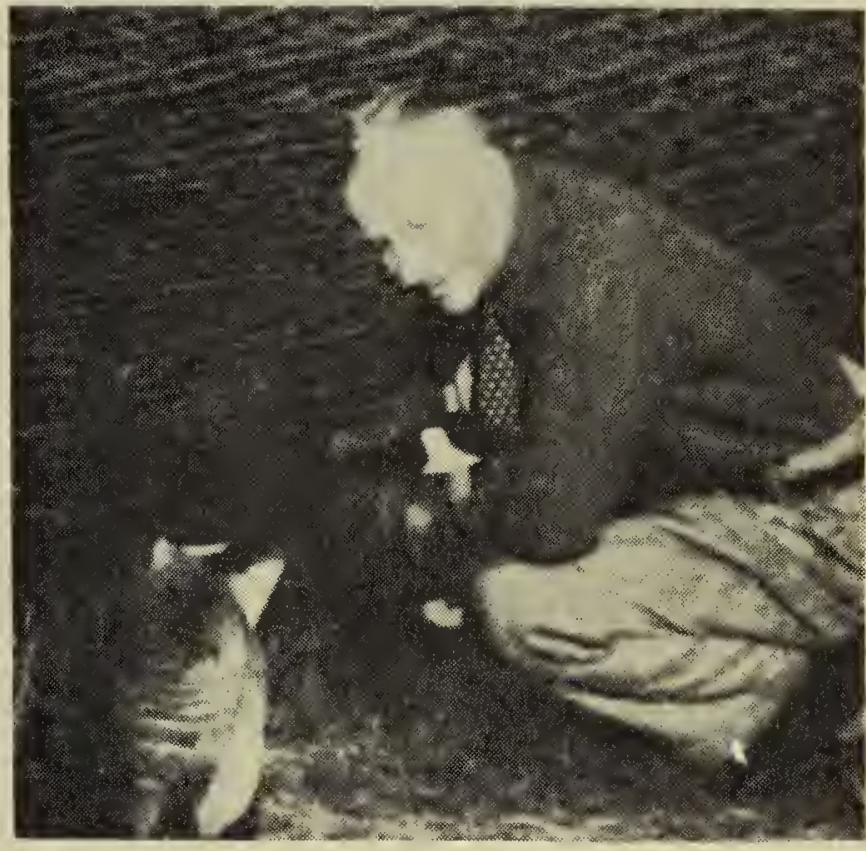

The author with Jonathan, his talk ing goose.

treasure of gold that will eventually be as asset to our Dominion.

Nature is a builder and soon, too soon, she has completed the building of summer. The wild ducks are flying about in small flocks. The Blackbirds are gathering in larger flocks. The swallows are sitting in rows on yonder tel ephone wire. The scene is "Fall". The farmers are anxiously wondering when the first frost will come. The leaves are turning colors of gay red, yellow and brown. The Qu'Appelle Valley is painted in scenes that an artist cannot duplicate. It is here for us to enjoy for perhaps three weeks, then one by one the leaves are falling back to old Mother Earth from whence they came.

Each day some new bird callspin to say goodbye. Soon the trees will be bare again, and the sounds of harvest will cease. Then silently little snowflakes will come floating down.

$\mathrm{C}$ an you guess the scene as the curtain rises once more. Kind folks, I am going to leave it for you to paint in your own hearts, and as you do let Nature help you build a cheery fireplace within. 